\title{
Transformation of Social and Economic Model in Asia-Pacific Region and its Implications for Russia's Turn to the East
}

\author{
Igor A. Makarov* \\ National Research University \\ Higher School of Economics \\ 20 Myasnitskaya Str., Moscow, 101000, Russia
}

Received 14.04.2016, received in revised form 27.08.2016, accepted 19.10.2016

Starting from 2012, the "turn to the East" in Russian internal and foreign policy has taken place. This turn supposes strengthening of economic and political relations with Asian states along with the rapid development of eastern territories and their conversion into the trigger of the country's economic development. In order to succeed in accomplishing the "turn", the better understanding of economic and political processes in the Asia-Pacific region (APR) is required. This article focuses on the transformation of the economic model undergone by Asian Pacific economies in the recent years. Such transformation is of high importance for Russia, since it defines the way in which the development of Russian eastern territories should change to fully satisfy the demands of Russian partners in Asia. Russia could become a major producer of resource-intensive goods in the APR. To do so, modern trans-border infrastructure, which would connect Russian producers with the potential markets, is to be built. Apart from that, given the shift of the "core" of economic growth in the APR to the western direction, the model of rapid development, applied in the Far East, ought to be extended to Siberia. In addition, the enhanced coordination in the development policies of these two regions is critical.

Keywords: Development of Siberia and Far East, turn to the East, the Asia-Pacific region, Silk Road Economic Belt.

DOI: 10.17516/1997-1370-2016-9-11-2552-2564.

Research area: economics.

\section{Introduction: Russia's turn to the East -} interim results and key issues

There were numerous attempts of the eastern territories development in the history of Russia. The current "turn to the East" in national policy started in 2012. Its main motive was the desire to use the opportunities offered to Russia by the rapid economic growth of Asian countries. In the pre-election article in February 2012, V.V. Putin directly urged to "catch" Chinese wind "in the sails" of our economy" (Putin, 2012).

It is obvious that for this task fulfilment, accelerated development of Russian territories, adjacent to China, was necessary. APEC summit in Vladivostok that took place in 2012 should have given it momentum, but it also required the

(C) Siberian Federal University. All rights reserved

* Corresponding author E-mail address: imakarov@hse.ru 
appearance of structure involved in the region's development on the ongoing basis. Initially, creation of a state corporation for Siberia and the Far East Development was proposed, it was initiated by the Minister for Emergency Situations S.K. Shoigu. But after a while this idea was abandoned, and in May 2012 the Ministry for the Development of the Russian Far East was established. As a result, Siberia dropped out of the plans for the eastern territories development. The only exception was the Baikal region, which, nevertheless, was included into the state programme "Socioeconomic Development of the Russian Far East and the Baikal Region" adopted in March 2013. Since then the program itself has undergone major changes, the minister was replaced, and in late 2013 a new model of the Far East development was approved. It involves attracting foreign capital and supporting industries oriented on exporting products to the growing Asian markets.

The institutional base of the turn to the East within the framework of this model was created in 2015: the law on the priority development areas (PDAs) was put into force, the status of Vladivostok as a free port was formalized, the first priority investment projects were approved and the Far East Development Corporation and Foundation started operation. It is early to judge the results of their activity; however, we can't but recognize that despite the efforts made, structural problems of Russia's turn to the East are here to stay. The economy of the eastern territories still has a purely resource-based nature; it is characterized by the lack of infrastructure and human capital. These problems are exacerbated by the crisis in the country's economy as a whole, as well as political risks due to the conflict between Russia and Western countries.

All these problems were manifested in the turnover dynamics between Russia and APR countries $^{1}$. In 2010 and 2011 it grew on average by
$42 \%$ per year (Fig. 1). In 2009 China surpassed Germany and became the main trading partner of Russia. Optimistic expectations about the future of bilateral trade are reflected in the joint statement of D.A. Medvedev and Hu Jintao in 2011, where the goals to bring the turnover between Russia and China to $\$ 100$ billion in 2015 and to $\$ 200$ billion to 2020 were set.

These goals turned out to be unattainable. In 2012, just at the time when the idea of Russia's turn to the East started to be discussed at the highest level, the growth rates of trade between Russia and China fell to 6\% (Fig. 2). In 2013 they decreased to $1 \%$, and in 2014 there was a general decline (-1\%) in the mutual trade. Trade with the Asia-Pacific Region as a whole demonstrated the similar dynamics (7\% growth in 2012, 3\% in 2013 and $1 \%$ decline in 2014).

In 2015 a real collapse took place: turnover between Russia and Asia-Pacific countries fell by $32 \%$. The only country in the region that managed to keep the volume of trade with Russia at the same level (it even increased by $1 \%$ ) was India. The largest decline occurred in trade between Russia and ASEAN countries (-41\%), but the decline in turnover with China, which by that time was invariably regarded as Russia's main strategic partner not only in the region but in the world, was the most dramatic (-31\%).

The unfavorable dynamics was observed in attracting investments, even from China. Despite the political support and a large number of the memorandums of intent signed at the highest level, the Chinese investments were limited to a few large transactions in the Russian energy sector with the participation of Chinese stateowned development banks and the Silk Road Fund. As for other Asia-Pacific countries, their investments in Russia have virtually stopped.

Against the background of unfavorable indicators of 2015, Russian intellectual circles and the media started massive criticism of Russia's 


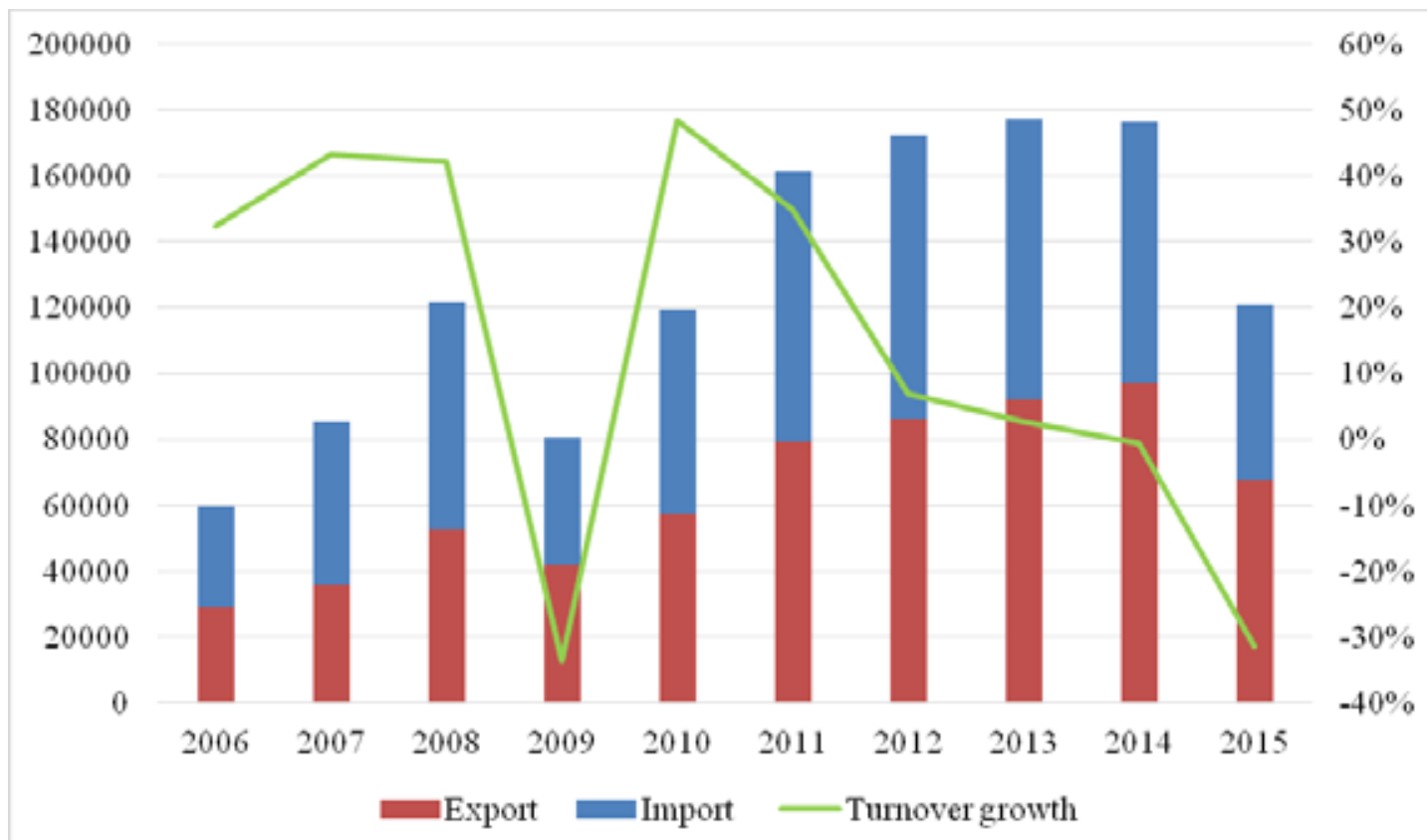

Fig. 1. Turnover between Russia and APR countries, USD mln (left axis), and the turnover growth rate in \% (right axis) in 2006-2015. Source: Federal Customs Service of the Russian Federation

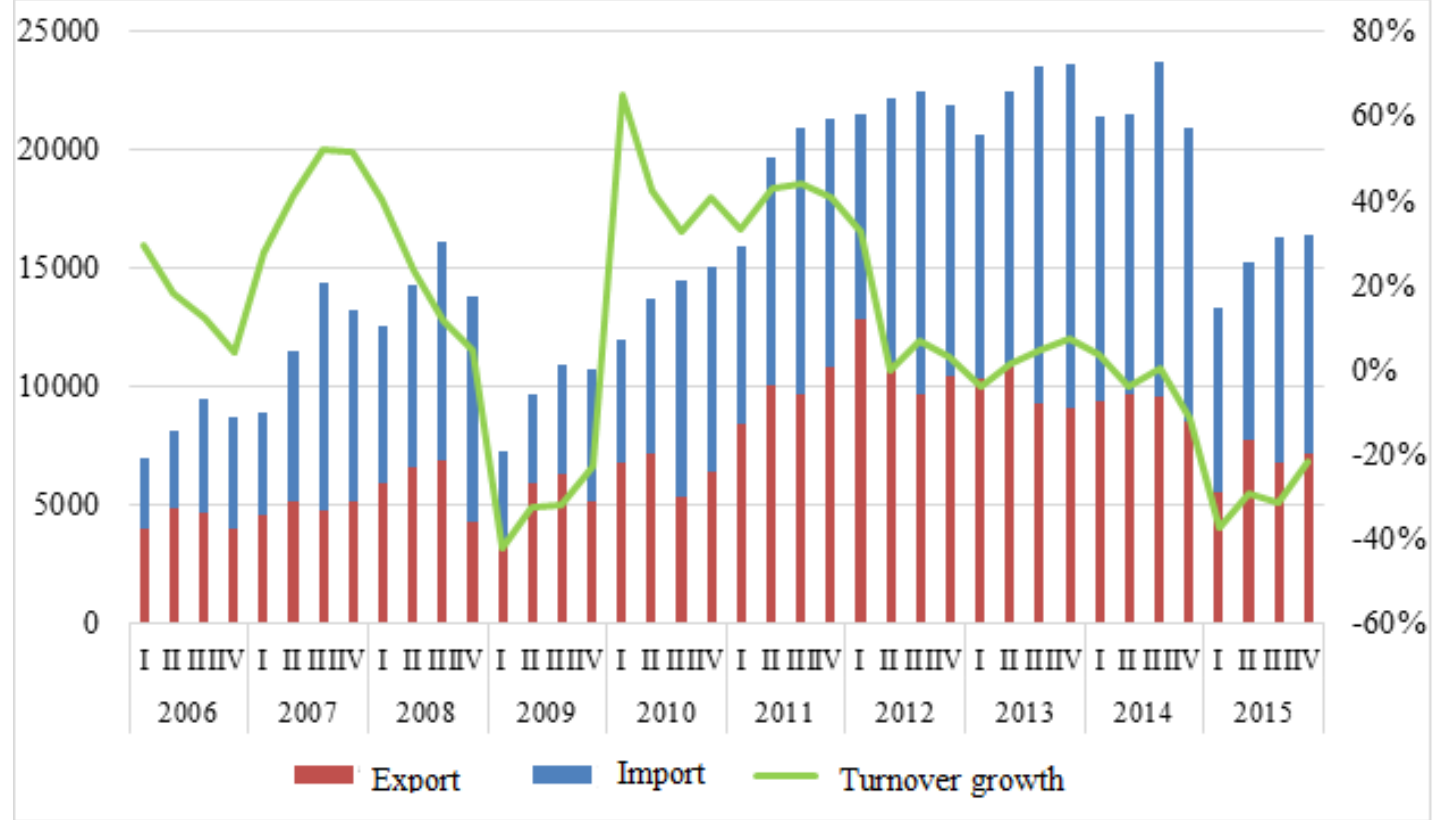

Fig. 2. Turnover between Russia and China, USD mln (left axis), \% (right axis) in 2006-2015. Source: Federal Customs Service of the Russian Federation 
turn to the East (Gabuev, 2015; Zadorozhnyi, 2016; Korostik, 2016). Much of this criticism is justified, though largely negative dynamics of trade, and investment cooperation is determined by the objective factors, first of all, by the drop in oil prices and general deterioration of the economic situation in Russia. It should be noted that in real terms the turnover between Russia and China in 2015 did not decrease. In addition, even at its cost, the share of Asia-Pacific countries in the volume of Russia's foreign trade in 2015 increased, as the Russia's turnover with other partners decreased even more. As for investments, their deceleration is determined by sanctions and high political risks - the factors that are not directly related to the turn to the East.

At the same time, it is wrong to attribute the failures of 2015 only to the set of common factors. The complexities of the Russia's turn to the East are not only of economic but fundamental nature. The major one lies in the fact that the model for the Russian Far East development, which was made a few years ago, is poorly adapted to the changes in the external environment. And most importantly - it is not adapted to the large-scale transformation that is currently taking place in the Asia-Pacific region.

\section{Transformation \\ of the economic model of the Asia-Pacific countries}

Over the past decade and a half Asian countries led by China have been the main engine of the worldeconomic development. South andEast Asia first became "the world's factory" providing the developed countries with cheap consumer goods. And currently they are gradually turning into one of the most diversified and self-sufficient regions of the world, adding developed clusters of high-tech industries, financial centers and more extensive infrastructure to the traditional specialization in consumer goods production.
Currently, a transformation of the economic model underlying the economic growth of the previous decades in Asia is taking place. Gradual exhaustion of the potential for extensive management practices on the one hand and new needs and opportunities created by the growth of revenues on the other are among the reasons for this transformation.

The essence of the transformation in the economic model of the Asian countries is in the following shifts taking place in the region (Makarov et al, 2015):

1. From the extensive economic growth based on the use of cheap labor and natural resources exploitation for the export-oriented industries development to intensive economic growth based on the increase in domestic consumption.

2. From the specialization in the primitive labor-intensive consumer goods to specialization in the production of relatively high quality and high technology good and services, aimed at meeting the growing needs of the middle class.

3. From the focus on exporting goods to the developed countries (the model of "Asia for the World") to focus on the value added chains development within Asian region (the model of "Asia for Asia").

4. From the accelerated development of coastal areas (the traditional "core" of the region's economic growth: the Republic of Korea, Taiwan, Hong Kong, Singapore, and China's eastern provinces) to the former periphery accelerated development: central and western provinces of China, as well as neighboring countries: from Mongolia and Central Asian republics to Vietnam and Myanmar.

Let us consider each of these shifts separately.

\section{Shift 1: The type of economic growth}

In the second half of the $20^{\text {th }}$ century Asian countries managed to create their own model of 
catching up economic growth based on exporting goods to the developed countries. Due to this model, Japan, the Republic of Korea, Taiwan and Singapore joined the ranks of the most developed countries in the world. Hereafter, it was successfully implemented in Malaysia, Thailand and particularly in China. Currently, all of these countries are gradually moving away from the model of export-oriented growth, which has significant implications for the region as a whole. Thus, from 2006 the ratio of exports to GDP in China has fallen from 36 to $21 \%$, in Malaysia from 96 to $68 \%$, in Singapore from 184 to $124 \%$ (Table 1).

Exhaustion of export-oriented growth model is most evidently demonstrated in China - the largest and the most important country in the region for Russia. Since the beginning of market reforms in the late 1970s the country's GDP has been increasing on average by $10 \%$ per year. Due to this, China now accounts for $15 \%$ of global output, and in the coming years it will become the largest economy of the world. However, in recent years, China is experiencing slowdown in economic growth. In 2015 it amounted only 6.8\%, it is the lowest value since 1990 (Table 2).

China's economic growth is of extensive nature and its deceleration is well explained by the neoclassical models of economic growth (e.g. the Solow-Swan model). In many ways China follows the way that was previously passed by the preceding regional leaders - Japan and South Korea that faced a structural slowdown in the late $20^{\text {th }}$ century. Chinese "economic miracle" was based on the use of cheap labor, investments into major infrastructure projects, natural resource extraction and predatory exploitation of the environment. The standard of living has significantly grown over the last decade, and the coastal provinces that made up the core of China's economic development, faced the "middle income trap". As a result, they are now less able to compete with other Asian countries on product value and with the West

Table 1. Export share in GDP structure of Asia-Pacific countries in 2006-2015

\begin{tabular}{|r|r|r|r|r|r|r|r|r|r|r|}
\hline & $\mathbf{2 0 0 6}$ & $\mathbf{2 0 0 7}$ & $\mathbf{2 0 0 8}$ & $\mathbf{2 0 0 9}$ & $\mathbf{2 0 1 0}$ & $\mathbf{2 0 1 1}$ & $\mathbf{2 0 1 2}$ & $\mathbf{2 0 1 3}$ & $\mathbf{2 0 1 4}$ & $\mathbf{2 0 1 5}$ \\
\hline China & $36 \%$ & $35 \%$ & $31 \%$ & $24 \%$ & $26 \%$ & $25 \%$ & $24 \%$ & $23 \%$ & $23 \%$ & $21 \%$ \\
\hline Japan & $15 \%$ & $16 \%$ & $16 \%$ & $12 \%$ & $14 \%$ & $14 \%$ & $13 \%$ & $15 \%$ & $15 \%$ & $15 \%$ \\
\hline India & $13 \%$ & $13 \%$ & $15 \%$ & $12 \%$ & $13 \%$ & $16 \%$ & $16 \%$ & $16 \%$ & $16 \%$ & $13 \%$ \\
\hline Republic of Korea & $32 \%$ & $33 \%$ & $42 \%$ & $40 \%$ & $43 \%$ & $46 \%$ & $45 \%$ & $43 \%$ & $41 \%$ & $38 \%$ \\
\hline Indonesia & $25 \%$ & $24 \%$ & $25 \%$ & $20 \%$ & $21 \%$ & $23 \%$ & $21 \%$ & $20 \%$ & $20 \%$ & $17 \%$ \\
\hline Thailand & $58 \%$ & $58 \%$ & $60 \%$ & $54 \%$ & $56 \%$ & $59 \%$ & $57 \%$ & $54 \%$ & $56 \%$ & $54 \%$ \\
\hline Malaysia & $96 \%$ & $88 \%$ & $84 \%$ & $75 \%$ & $78 \%$ & $77 \%$ & $72 \%$ & $71 \%$ & $69 \%$ & $68 \%$ \\
\hline Singapore & $184 \%$ & $166 \%$ & $176 \%$ & $140 \%$ & $149 \%$ & $149 \%$ & $141 \%$ & $136 \%$ & $133 \%$ & $124 \%$ \\
\hline Philippines & $39 \%$ & $34 \%$ & $28 \%$ & $23 \%$ & $26 \%$ & $22 \%$ & $21 \%$ & $21 \%$ & $22 \%$ & $20 \%$ \\
\hline Vietnam & $60 \%$ & $62 \%$ & $63 \%$ & $54 \%$ & $62 \%$ & $70 \%$ & $74 \%$ & $77 \%$ & $81 \%$ & $84 \%$ \\
\hline Myanmar & $31 \%$ & $31 \%$ & $22 \%$ & $18 \%$ & $17 \%$ & $15 \%$ & $15 \%$ & $18 \%$ & $17 \%$ & $17 \%$ \\
\hline Cambodia & $52 \%$ & $51 \%$ & $45 \%$ & $40 \%$ & $46 \%$ & $54 \%$ & $58 \%$ & $59 \%$ & $64 \%$ & $65 \%$ \\
\hline Brunei & $60 \%$ & $57 \%$ & $65 \%$ & $61 \%$ & $65 \%$ & $67 \%$ & $68 \%$ & $63 \%$ & $61 \%$ & $91 \%$ \\
\hline Laos & $25 \%$ & $20 \%$ & $21 \%$ & $19 \%$ & $26 \%$ & $27 \%$ & $24 \%$ & $21 \%$ & $23 \%$ & $23 \%$ \\
\hline ASEAN countries & $36 \%$ & $33 \%$ & $34 \%$ & $28 \%$ & $29 \%$ & $29 \%$ & $29 \%$ & $29 \%$ & $28 \%$ & $26 \%$ \\
\hline
\end{tabular}

Source: Euromonitor 
Table 2. GDP growth rate in Asia-Pacific countries in 2006-2015 (in current prices)

\begin{tabular}{|r|r|r|r|r|r|r|r|r|r|r|}
\hline & $\mathbf{2 0 0 6}$ & $\mathbf{2 0 0 7}$ & $\mathbf{2 0 0 8}$ & $\mathbf{2 0 0 9}$ & $\mathbf{2 0 1 0}$ & $\mathbf{2 0 1 1}$ & $\mathbf{2 0 1 2}$ & $\mathbf{2 0 1 3}$ & $\mathbf{2 0 1 4}$ & $\mathbf{2 0 1 5}$ \\
\hline China & $12.7 \%$ & $14.2 \%$ & $9.6 \%$ & $9.2 \%$ & $10.4 \%$ & $9.3 \%$ & $7.7 \%$ & $7.7 \%$ & $7.3 \%$ & $6.8 \%$ \\
\hline Japan & $1.7 \%$ & $2.2 \%$ & $-1.0 \%$ & $-5.5 \%$ & $4.7 \%$ & $-0.6 \%$ & $1.9 \%$ & $1.8 \%$ & $0.0 \%$ & $0.5 \%$ \\
\hline India & $9.3 \%$ & $9.8 \%$ & $3.9 \%$ & $8.5 \%$ & $10.5 \%$ & $6.3 \%$ & $3.2 \%$ & $4.9 \%$ & $5.6 \%$ & $7.4 \%$ \\
\hline Republic of Korea & $5.2 \%$ & $5.1 \%$ & $2.3 \%$ & $0.3 \%$ & $6.3 \%$ & $3.7 \%$ & $2.0 \%$ & $2.7 \%$ & $3.3 \%$ & $2.6 \%$ \\
\hline Indonesia & $5.5 \%$ & $6.3 \%$ & $6.0 \%$ & $4.6 \%$ & $6.2 \%$ & $6.5 \%$ & $6.2 \%$ & $5.7 \%$ & $5.0 \%$ & $4.7 \%$ \\
\hline Thailand & $4.9 \%$ & $5.4 \%$ & $1.7 \%$ & $-0.9 \%$ & $7.3 \%$ & $0.3 \%$ & $6.4 \%$ & $3.0 \%$ & $0.7 \%$ & $2.8 \%$ \\
\hline Malaysia & $5.6 \%$ & $6.3 \%$ & $4.8 \%$ & $-1.5 \%$ & $7.4 \%$ & $5.1 \%$ & $5.6 \%$ & $4.0 \%$ & $6.0 \%$ & $4.8 \%$ \\
\hline Singapore & $8.6 \%$ & $9.0 \%$ & $1.7 \%$ & $-0.8 \%$ & $14.8 \%$ & $5.2 \%$ & $1.3 \%$ & $3.0 \%$ & $2.9 \%$ & $1.7 \%$ \\
\hline Philippines & $5.2 \%$ & $6.6 \%$ & $4.2 \%$ & $1.1 \%$ & $7.6 \%$ & $3.6 \%$ & $6.8 \%$ & $7.0 \%$ & $6.1 \%$ & $5.4 \%$ \\
\hline Vietnam & $7.0 \%$ & $7.1 \%$ & $5.7 \%$ & $5.4 \%$ & $6.4 \%$ & $6.2 \%$ & $5.2 \%$ & $5.2 \%$ & $6.0 \%$ & $6.7 \%$ \\
\hline Myanmar & $13.1 \%$ & $12.0 \%$ & $10.3 \%$ & $10.6 \%$ & $10.2 \%$ & $6.0 \%$ & $6.3 \%$ & $5.3 \%$ & $8.5 \%$ & $8.5 \%$ \\
\hline Cambodia & $10.8 \%$ & $10.2 \%$ & $6.7 \%$ & $0.1 \%$ & $6.0 \%$ & $7.1 \%$ & $7.3 \%$ & $6.9 \%$ & $7.2 \%$ & $7.0 \%$ \\
\hline Brunei & $4.4 \%$ & $0.2 \%$ & $-1.9 \%$ & $-1.8 \%$ & $2.6 \%$ & $3.4 \%$ & $0.9 \%$ & $1.8 \%$ & $5.3 \%$ & $-1.2 \%$ \\
\hline Laos & $8.6 \%$ & $7.8 \%$ & $7.8 \%$ & $7.5 \%$ & $8.1 \%$ & $8.0 \%$ & $7.9 \%$ & $8.0 \%$ & $7.4 \%$ & $7.5 \%$ \\
\hline & $6.0 \%$ & $6.7 \%$ & $4.1 \%$ & $1.6 \%$ & $8.0 \%$ & $4.6 \%$ & $5.4 \%$ & $4.7 \%$ & $4.7 \%$ & $4.6 \%$ \\
\hline
\end{tabular}

Source: Euromonitor

on quality (Woo, 2012; Zhuang, Vandenberg, and Huang, 2012). Infrastructure projects also may no longer serve as a driver for development: the necessary infrastructure, at least in the east of China, has already been built. Pollution and natural resources depletion is another obstacle to economic growth.

At the same time, social costs of extensive economic growth are growing. Its positive effects expressed in the growth of living standards are observed throughout the country, but they are distributed unevenly. The results are the sharp increase in income inequality and aggravation of regional disparities (Xie, Zhou, 2014). Mechanisms of social security and overall provision of public services that could act as a mitigating factor are still very poorly developed. In its turn, the increase in the demographic load, which is a consequence of the prolonged use of "one family - one child" policy in China (Cai, 2012), creates additional prerequisites for the growth of social tension. Request for social justice is growing as well.
The aforementioned contradictions resolution within the previous model of economic growth is impossible. The need for transformation was discussed a long time ago, even before the financial and economic crisis; however a package of measures to support the economy, adopted in 2008, was still based on public investment into the fixed assets: infrastructure development and housing construction, incentives for innovation, etc. The use of this package led to the fact that the transformation was postponed until the $18^{\text {th }} \mathrm{CPC}$ Congress in November 2012, when structural reforms were announced. Their idea was to refocus on the expansion of domestic demand as the main engine of economic growth, as well as on the priority development of new industries: modernized manufacturing industry ensuring a close connection between science and production, as well as the service sector (Grigor'ev, Kul'pina, 2013; Zhang and Zhang, 2013). However, this transition is still being carried out with difficulty. Numerous structural problems connected with the public sector inefficiency, weak banking system, 
regional disparities, aging population and weak institutions do not allow China to overcome the slowdown.

Changing socio-economic model of China's development entails transformation of the entire structure of international economic relations in the Asia-Pacific region. Almost all the countries in the region are moving to the model "Asia for Asia", orienting its foreign external economic specialization to China's demands and, along with it, to the other leading Asian countries Japan and Korea that consumption patterns are similar to those of the richest provinces of China (Likhacheva, Bordachev, and Zhang, 2014). And this transformation is a chance for rapid economic growth of the countries that previously were at the periphery of the region and significantly lagged both in the level and rates of socio-economic development.

\section{Shift 2: Sectoral structure of economy}

Rapid income growth in Asia-Pacific countries has led to the emergence of larger middle class in the cities of the region, gradually shifting to the model of consumption, characteristic of the developed countries. There is a growing demand for different types of food and consumer goods of relatively high quality, cars, luxury items and various forms of entertainment and, at the same time, for education, healthcare and other public services.

Service sector demonstrates the biggest growth. Since 2000 its share in GDP has increased in all the countries of Asia-Pacific region except Thailand. In China, the growth was from 39\% in 2000 to $47 \%$ in 2015 . Along with that, almost everywhere (with the exception of Thailand, Malaysia and Indonesia), the share of agriculture is reducing (Euromonitor).

Major changes are taking place in the industrial sector structure. A half of its production is made up of five sectors: metallurgy, chemical industry, food industry, machinery and equipment production, as well as vehicles. After the financial crisis of 2008-2009 these industries demonstrated the growth of $6-10 \%$ per year. Among other sectors, those associated with the consumer durables production, such as furniture industry, were developing most dynamically (Euromonitor).

Although changes in the sectoral structure of economy differ from country to country, some trends are common. The major of them is movement towards more complex productions. The developed countries of the region, especially Japan, Korea, Singapore and Taiwan have already become the centers of high-tech goods and services. Now this specialization is picked up by the most affluent regions of China, India and ASEAN. Developing countries, as well as central and western provinces of China, previously specialized in agriculture, are gradually turning into the "world factory". The role of agriculture is increasing only where it is commercialized and focused on exports, such as Thailand, Vietnam and Malaysia.

Changes in the sectoral structure of Asian economies could have serious implications for the main exporters of goods to the region. For the accurate assessment of such effects, a detailed analysis in terms of industries and commodity groups is required. Nevertheless, some of the key consequences could be on the basis of the aggregated statistics. In particular, China's refocusing from industry and construction to the service sector has already reduced its demand for imported products. This decline, exacerbated by the completion of the era of large-scale infrastructure projects and the bursting bubble in the property market, has particularly affected imports of raw materials. At the same time, new niches associated with the growing demand for consumer goods and services, many of which can not be produced domestically, appear in the Asian market. Consumer spending for food is 
growing, which, in line with the declining share of agriculture in most Asia-Pacific countries, leads to the increase in agricultural goods imports (Makarov, et al., 2016).

\section{Shift 3: Export geography}

Income growth in the eastern provinces of China has led to the increase in labor costs of the productions placed here, which was a key factor of the transfer of some of them to the central and western provinces, as well as to other countries. In 2015 the minimum monthly salary in China ranged from $\$ 137$ to $\$ 639$ depending on province. Among other Asia-Pacific developing countries it had comparable values (\$381 and \$254 respectively) only in Thailand and Malaysia. The minimum wage in Vietnam was \$101-142 per month, in Indonesia \$71-230, in Philippines $\$ 110-220$, in Laos \$110. In South Asian countries the minimum wages were even lower: $\$ 40-130$ in India, \$ 49-72 in Sri Lanka, \$68 in Bangladesh (Knowler, 2015). Even in Russia, after the ruble devaluation in 2014-2015, the average salary in dollars for the first time was lower than in China.

Another important reason that pushes Chinese and multinational corporations to transfer their production from China to other countries, is a high social tax, the average value of which amounts $35 \%$. It is significantly lower than in other countries in the region: $22 \%$ in Vietnam, $13.7 \%$ in Malaysia, 9.2\% in Indonesia, $8.8 \%$ in the Philippines, $5.2 \%$ in Thailand, $7.4 \%$ on average in India (Likhacheva, Bordachev, and Zhang, 2014).

Production transfer from China is most typical for the labor-intensive industries, such as textiles. A few decades ago it was one of the foundations of the Chinese "economic miracle". Currently, most of the industry enterprises are already placed in Vietnam, Myanmar, Bangladesh and other relatively poor countries of the Asia-Pacific region. The textile industry and other primitive labor-intensive industries in the eastern provinces of China are replaced by the more technologically complex ones, for example, automotive industry and electronics. They, in turn, are transferred from the developed countries - Japan and the Republic of Korea.

Newly emerging in the region network of investment flows, accompanying the transfer of industries, is supplemented by a new system of intra-regional trade. Previously, Asian export was focused on the developed countries. However, stagnating demand in the European Union and growing consumption in Asia led to the shift in export flows to intraregional markets. In 2000 only $48.9 \%$ of Asian exports stayed within the region. Since the late 2000s this figure began to grow and by 2014 it reached $52.3 \%$ (WTO). The model "Asia for the World", where Asian countries had the status of the "world factory" serving the developed countries, was replaced by the model of "Asia for Asia". The region remains the "world factory" (though specializing in more complex productions), but its products are already focused on meeting intra-Asia demand.

The shift from inter-regional to intraregional trade contributes to the development of trade liberalization processes in the region. In particular, in recent years free trade agreements between China and ASEAN (2012), as well as between China and the Republic of Korea (2015) have been signed. The Transpacific Partnership Agreement (TPP) signing and the probable launch of the Regional Comprehensive Economic Partnership (RCEP) will contribute to the further refocusing of Asian countries' production on intra-regional markets.

\section{Shift 4: Geography of Economic Growth}

Economic growth in the Asia-Pacific region has always been uneven. Initially, its "core" was in Japan, then it moved to the "Four Asian Tigers" and then to the eastern provinces of China. Currently, the "core" of economic growth 
is transferred to the territories that were formerly the "periphery". On the one hand, it happens due to the structural slowdown in the eastern provinces of China (shift 1), and on the other, in connection with the active transfer of production to the relatively poor countries and regions (shift 3).

The highest economic growth rates are demonstrated by the areas of the former periphery that managed to fit into the value added chains of international companies, focused on meeting the needs of the Chinese market. Mongolia, for example, demonstrated the world highest GDP growth rates in 2011-2013 - an average of 13.9\% (World Development Indicators). The poor countries in Southeast Asia are currently following the same way. Central Asian Republics also aspire to become one of the growth poles due to the Chinese project of the Silk Road Economic Belt.

The geography of economic growth within China is changing as well. From the eastern provinces the productions are moved to the central and western ones, where labor force and the land is cheaper, transport infrastructure is dynamically developing and demand has a huge potential for expansion in the nearest future. As a consequence, the central and western provinces of China have been showing the best economic dynamics in recent years (Fig. 3).

As shown above, China's economic growth rate after the crisis was much lower than before the crisis. This is also true for the majority of the provinces. For example, the average GDP growth rate in Shanghai in the period of 20092014 was 4.1 p. p. lower than in 2004-2008, in Zhejiang - 4.3 p. p., in Inner Mongolia - 7.6 p. p. In the provinces of the Center and the West, on the contrary, economic growth rate increased: by 1 p. p. in Chongqing and Guizhou, and 0.8 p. p. in Yunnan (National Bureau of Statistics of China).

An important factor of the economic growth transference to the West could become the strengtheningof China's cooperation with the countries of Central Asia and development of the Silk Road Economic Belt (Bordachev, et al., 2015). If a transport corridor to Europe is to be established within it, the western provinces, especially Xinjiang Uygur Autonomous Region, will acquire new strategic importance and will become a major international transport hub.

\section{The significance of the Asia-Pacific} region economic model transformation for Russia's turn to the East

Shifts, taking place in South and East Asia are of great importance for Russia. One of the reasons of the fact that Russia's economic turn to the East is taking place very slowly is ignoring them. The strategy for Siberia and the Far East integration into the Asia-Pacific region should come from the understanding of these territories' place and their role in the new Asia, taking into

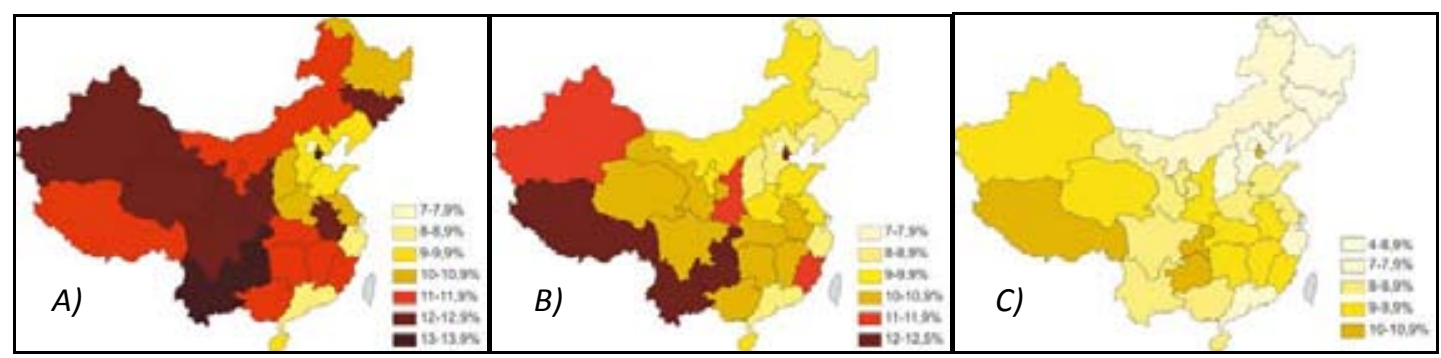

Fig. 3 The rate of GRP growth in Chinese provinces in 2012 (A), 2013 (B) and 2014 (C). Source: National Bureau of Statistics of China 
account all the consequences of the transformation taking place in the region.

Under conditions of changing the type of economic growth and transformation in the sectoral structure of economy, the need of AsiaPacific countries in the Russian raw materials in the coming years is unlikely to grow rapidly, with the exception of certain goods (e.g. natural gas, which is in demand, taking into account the desire of China to reduce their dependence on coal on the basis of environmental considerations). At the same time, the demand for consumer goods and services will inevitably increase. Russia's economy is not competitive in the production of those that are labor or capital intensive (although there are exceptions - for example, some types of software). In this regard, the task of Russia is to enter the model "Asia for Asia" as a key manufacturer (for the needs of the growing consumption of the "core" countries and provinces) of resource intensive goods. Specializing in these goods production (preferably, in the most hightech versions) and exporting them to the AsiaPacific countries will allow to take advantage of Asian countries resource constraints, as well as to implement the competitive advantages of Eastern Russia: abundance of hydrocarbons, fresh water, arable land, hydropower, forest and fish resources, etc.

The most promising product groups are food (especially grain), wood processing industry products, paper and pulp, certain types of metallurgical goods (e.g., high-quality aluminum goods, produced with the use of energy resources of Eastern Siberia), fish resources, ecotourism, data storage and processing services (data processing) (Makarov, et al., 2014).

A key condition for the production transfer and intra-regional value added chains participation is the cross-border infrastructure development, which connects Russia with the Asian countries, primarily the transport one.
There are some possibilities for this in the Far East, in particular, the transport corridors of Primorye, connecting the provinces of the northeast of China with the Russian ports on the Pacific coast. "Primorye - 1", "Primorye - 2" and "Primorye -3 " corridors are mainly focused on transit, but they may also be used for the deliveries of Russian goods to China.

Another opportunity is trans-Korean infrastructure development-mainly railway, which will facilitate Russian goods entering the market of the Republic of Korea. At present, negotiations on this project are on hold because of the worsening of the political situation on the Korean peninsula, however, there will be opportunity to return to them later: South Korea does not abandon its Eurasian initiative that will hardly be successfully implemented without Russia.

Transport corridor China - Mongolia Russia, which will connect East Siberia with the central and western provinces of China-just those where the core of economic growth is transferred to, can be of potentially great importance for Russia's integration into the model "Asia for Asia" (Likhacheva, Makarov, 2016).

And finally, perhaps the main project for Russia - the Silk Road Economic Belt (SREB), connecting China with Central Eurasia and able to create a new center of economic growth in the region. On 8 May 2015 V.V. Putin and Xi Jinping signed a joint statement on cooperation in conjunction of SREB and the Eurasian Economic Union (EAEU), laying the foundation for mutually beneficial cooperation between the two countries in the region.

Taking into account the SREB launch and gradual turn of China to the West, the integrated approach to the management of Siberia and the Far East is becoming no longer just desirable, but necessary. These are the integral parts of one macro-region. They are linked historically: from the time of Russian explorers the name "Siberia" 
was referred to the entire territory from the Ural Mountains to the Pacific Ocean. A special identity was formed in this territory, personified by the right head of the double-headed eagle on the national coat of arms. Siberia and the Far East are actively interacting with each other at the level of economic relations and human contacts - often more active than with Moscow. And finally, they are interrelated in their infrastructure - through the Trans-Siberian Railway and the Northern Sea Route.

The economic potential of Siberia in general is higher than the economic potential of the Far East. The population of the Siberian Federal District is 19.3 million people and the Far Eastern Federal District - 6.2 million people (with the bigger territory). The Siberian Federal District is similarly rich in natural resources: raw hydrocarbons, coal, uranium, ferrous, nonferrous, rare earth and precious metals, wood, water and hydropower resources. The stocks of coal in Siberia account for 80 percent of Russian reserves, copper - 70 percent, nickel 68 per cent, lead -86 percent, zinc -77 percent, molybdenum -82 percent, gold -41 percent, the platinum group metals - 99 percent, hydropower resources and timber reserves - more than 50 percent. The region is also rich in extensive cropland under more favorable climate than in the Far East. But the main thing is that opportunities for the high added value industries development are incomparably better. Human potential is also much more developed: there are five Siberian universities in the top twenty Russian universities ranking and there isn't any Far Eastern one in it (Makarov, 2016).
The main curse of Siberia is its continental nature, distance from the key commodity markets, supplemented by the weak development of transport infrastructure. The Silk Road Economic Belt project opens new possibilities for Siberia. If the region is able to fit into the transport and industrial cluster being established in the Central Eurasia, it can take on a new lease of life, turning the drawbacks of its geographical position into benefits (Makarov, Sokolova, 2016).

Accelerated development of the Far East without regard to its close relationship with Siberia will inevitably lead - through the transport capacity utilization - to worsening the continental situation of the latter. Meanwhile, on the contrary, one of the purposes of the Far East infrastructure development should be to make Siberia "closer" to the external markets. However, it is difficult to demand it from the Ministry for the Development of the Russian Far East, as Siberia is not included in the scope of its responsibility.

Now, when the Far East development institutions started their operation, coordinating the development of this region and Siberia is the next important task within the framework of the Russian Far East accelerated development policy. It is best to be implemented in parallel with the development of specific mechanisms for coupling the Eurasian integration project with the Silk Road Economic Belt. The processes taking place in the Asia-Pacific region and in Central Eurasia unfold very rapidly, and it is important for Russia to keep pace with them. The turn to the East itself is a decade late for the rapid economic growth of East Asian countries. Now it is important not to repeat the previous mistakes.

\footnotetext{
The term "Asia-Pacific Region" is used in different meanings. In this paper, it includes China, Japan, the Republic of Korea, the ASEAN states and India.
}

\section{References}

Bordachev, T.V., Bezborodov, A.A., Gabuev, A.T., Kuzovkov, K.V., Makarov, I.A., Makarova, E.A., Skriba, A.S., Suslov, D.V., Timofeev, I.N. (2015). K Velikomu Okeanu-3. Sozdanie Tsentral 'nuiu Evraziiu. Ekonomicheskii poias Shelkovogo Puti i prioritety sovmestnogo razvitiia evraziiskikh 
gosudarstv. [Toward the Great Ocean-3. Creating Central Eurasia. The Silk Road Economic Belt and the Priorities of the Eurasian States' Joint Development]. Moscow, Valdai Discussion Club.

Cai, F. (2012). The Coming Demographic Impact on China's Growth: The Age Factor in the Middle-Income Trap, In Asian Economic Papers, 11 (1).

Gabuev, A.T. (2015). Povotor v nikuda: itogi aziatskoi politiki Rossii v 2015 godu. [Turn to nowhere: Results of Asian policy of Russia in 2015]. Moskovskii tsentr Karnegi. Available at: http:// carnegie.ru/commentary/2015/12/29/ru-62369/ioe2

Grigor'ev, L.M., Kul'pina, V.P. (2013). Kitai: problemy novogo etapa razvitiia. [China: Challenges of a New Stage of Development], In Mirovaia ekonomika v nachale XXI veka [World Economy in the Early $21^{\text {st }}$ Century]. Directmedia Publishing.

Knowler, G. (2015). Sourcing Report Reveals Scale of China's Rising Labor Costs. Joc. com. Available at: http://www.joc.com/international-logistics/sourcing-report-reveals-scalechina\%E2\%80\%99s-rising-labor-costs_20150415.html

Korostikov, M. (2016). Uroki kitaiskogo. [Lessons of Chinese], In Kommersant-Vlast'. Available at: http://www.kommersant.ru/doc/2906658

Likhacheva A.B., Bordachev T.V., Zhang X. (2014) What Asia Wants, or the "Four C's": Consumption, Connectivity, Capital \& Creativity, In Valdai International Discussion Club Publication, No. 1.

Likhacheva, A.B., Makarov, I.A. (2015). Sibir' i Dal'nii Vostok na novoi infrastrukturnoi karte Evrazii. [Siberia and Far East on a New Eurasia Infrastructure Map], In Povorot na Vostok. Razvitie Sibiri i Dal'nego Vostoka v usloviyakh usileniya aziatskogo vectora vneshney politiki Rossii [Turn to the East. Development of Siberia and the Far East under Conditions of Asian Vector Straightening in in Russia's Foreign Policy]. Moscow, Mezhdunarodnye otnosheniya, 313-329.

Makarov, I.A. (2015). Sibir‘ i Dal'nii Vostok kak vozmozhnyi lokomotiv rossiiskogo ekonomikopoliticheskogo razvitiia. [Siberia and Far East as a Potential Stimulus for Russian Economic and Political Development], In Povorot na Vostok. Razvitie Sibiri i Dal'nego Vostoka v usloviyakh usileniya aziatskogo vectora vneshney politiki Rossii [Turn to the East. Development of Siberia and the Far East under Conditions of Asian Vector Straightening in Russia's Foreign Policy]. Moscow, Mezhdunarodnye otnosheniya, Turn to the East. Development on Siberia and Far East under strengthening of Asian vector. Moscow, Mezhdunarodnye otnosheniya, 176-200.

Makarov, I.A., Barabanov, O.N., Bordachev, T.V., Kanaev, E.A., Larin, V.L., Ryzhkov, V.A. (2014). K Velikomu Okeanu - 2, ili Rossiiskii ryvok k Azii. [Toward the Great Ocean - 2, or Russia's Breakthrough to Asia]. Moscow, Valdai Discussion Club.

Makarov, I.A., Likhacheva, A.B., Sokolova, A.K., Stepanov, I.A., Pestich, A.S. (2015). Transformatsiia sotsial'no-ekonomicheskogo razvitiia aziatskikh stran. [Transformation of Social and Economic Model of Asian Countries Development]. In Povorot na Vostok. Razvitie Sibiri i Dal'nego Vostoka v usloviyakh usileniya aziatskogo vectora vneshney politiki Rossii [Turn to the East. Development of Siberia and the Far East under Conditions of Asian Vector Straightening in Russia's Foreign Policy]. Moscow, Mezhdunarodnye otnosheniya, 24-56.

Makarov, I.A., Sokolova, A.K. (2016). Sopryazhenie evraziyskoy integratsii i ekonomicheskogo poiasa Shelkovogo puti: vozmozhnosti dlya Rossii. [Coordination of Eurasian Integration and the Silk Road Economic Belt: Opportunities for Russia], In Vestnik mezhdunarodnykh organizatsiy [International Organizations Bulletin], 11 (2), 46-52. 
Putin, V.V. (2012). Rossiia i meniaiushiisia mir. [Russia and Changing World], In Moskovskie novosti. Available at: http://www.mn.ru/politics/20120227/312306749.html

Woo, W.T. (2012). China Meets the Middle-Income Trap: the Large Potholes in the Road to Catching-up, In Journal of Chinese Economic and Business Studies, 10 (4), 313-336.

Xie, Y., Zhou, X. (2014). Income Inequality in Today's China, In Proceedings of the National Academy of Sciences, 111 (19).

Zadorozhnyi, A. (2016). Kak provalilsia «povorot na Vostok». [How “Turn to the East” Failed]. Znak. com. Available at: https://www.znak.com/2016-01-19/kitay_ne_spaset_putinomiku_i_ne_sobiralsya

Zhang S., Zhang C. (2013). Chinese Economy and Reform after the 18th CCP National Congress. A Macroeconomic Analysis. Asia Research Centre at Copenhagen Business School, Institute of Economics Beijing. Quarterly Economic Brief.

Zhuang, J., Vandenberg, P., Huang, Y. (2012). Growing Beyond the Low-Cost Advantage. How the People's Republic of China Can Avoid the Middle-Income Trap. Asian Development Bank.

\title{
Трансформация социально-
}

экономической модели стран АТР

и ее последствия для российского поворота

\section{на Восток}

\author{
И.А. Макаров \\ Национальный исследовательский университет \\ Высшая школа экономики \\ Россия, 101000, Москва, ул. Мясниџкая, 20
}

\begin{abstract}
В 2012 г. начался поворот на Восток во внешней и внутренней политике России, предполагаюший укрепление экономических и политических отношений с азиатскими государствами, а также ускоренное развитие восточных территорий, превращение их в двигатель экономического роста всей страны. Поворот на Восток не может быть успешным без понимания экономических и политических прочессов, происходящих внутри Азиатско-Тихоокеанского региона (АТР). В данной статье рассмотрена трансформачия модели соииально-экономического развития, которую проходят экономики государств АТР в последние годы. Она имеет большое значение для России, определяет, в какую сторону должна видоизменяться модель развития ее восточных территорий для того, чтобы максимально удовлетворить запросы азиатских партнеров. В трансформирующейся Азии Россия имеет возможность стать ключевым производителем ресурсоемких товаров. Для этого необходимо в первую очередь развитие трансграничной инфраструктуры, связывающей российских производителей с потенциальными рынками сбыта. Кроме того, с учетом постепенного перемещения ядра экономического роста в АТР в западном направлении необходимым является распространение применяемой на Дальнем Востоке модели ускоренного развития на Сибирь, а также лучшая координация развития этих двух регионов.
\end{abstract}

Ключевые слова: развитие Сибири и Дальнего Востока, поворот на Восток, АзиатскоТихоокеанский регион, экономический пояс Шелкового пути.

Научная специальность: 08.00.00 - экономические науки. 